\title{
Water quality assessment of the Ganges River during COVID-19 lockdown
}

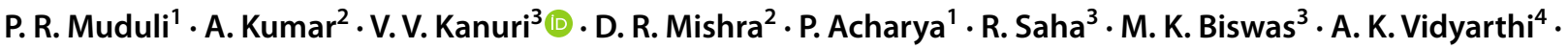 \\ A. Sudhakar ${ }^{4}$
}

Received: 19 October 2020 / Revised: 7 January 2021 / Accepted: 25 February 2021 / Published online: 9 March 2021

(c) Islamic Azad University (IAU) 2021

\begin{abstract}
Ganges River water quality was assessed to record the changes due to the nation-wide pandemic lockdown. Satellite-based (Sentinel-2) water quality analysis before and during lockdown was performed for seven selected locations spread across the entire stretch of the Ganges (Rishikesh-Dimond Harbour). Results revealed that due to the lockdown, the water quality of the Ganges improved with reference to specific water quality parameters, but the improvements were region specific. Along the entire stretch of Ganges, only the Haridwar site showed improvement to an extent of being potable as per the threshold set by the Central Pollution Control Board, New Delhi, India. A 55\% decline in turbidity at that site during the lockdown was attributed to the abrupt halt in pilgrimage activities. Absorption by chromophoric dissolved organic matter which is an indicator of organic pollution declined all along the Ganges stretch with a maximum decline at the downstream location of Diamond Harbour. Restricted discharge of industrial effluent, urban pollution, sewage from hotels, lodges, and spiritual dwellings along the Ganges are some of the reasons behind such declines. No significant change in the geographic trend of chlorophyll-a was observed. The findings of this study highlight the importance of regular monitoring of the changes in the Ganges water quality using Sentinel-2 data to further isolate the anthropogenic impact, as India continues the phase-wise opening amidst the pandemic.
\end{abstract}

Keywords Anthropogenic effect $\cdot$ Chlorophyll-a $\cdot$ Chromophoric dissolved organic matter $\cdot$ Sentinel- $2 \cdot$ Total suspended matter · Tropical River

Editorial responsibility: Samareh Mirkia.

V. V. Kanuri

vishnuchemistry@gmail.com

1 Wetland Research and Training Centre, Chilika Development Authority, Balugaon 752030, India

2 Department of Geography, University of Georgia, Athens, GA 30602, USA

3 Eastern Regional Directorate (ERD), Ministry of Environment, Forest and Climate Change, National Ganga River Basin Authority, Central Pollution Control Board, 5th and 6th floor, Southend conclave, Rajdanga Main Road, Kolkata, West Bengal 700107, India

4 Central Pollution Control Board, Ministry of Environment, Forest and Climate Change, New Delhi, India

\section{Introduction}

India's Corona virus disease (COVID-19) phase-wise lockdown initiated on 24th March 2020 is still ongoing at different phases with changes in restrictions in several sectors depending on the regional cases. The travel restrictions and urban activities were relaxed with each phase starting from a total ban during Phase-1 for 21 days. Recently, several rapid environment assessment studies have come out with initial assessments of the impact of the lockdown on the water quality of inland and coastal waters in India (Mishra et al. 2020; Garg et al. 2020; Mukherjee et al. 2020; Dhar et al. 2020). The Ganges River with $2601 \mathrm{~km}$ of length has been exposed to extreme pollution over the past few decades as reported by the Central Pollution Control Board (CPCB), India. Because of the lockdowns, most of the industries, tourism activities, pilgrimage, hotels and lodges, shops in proximity to all these establishments, which are the major source of pollution to the Ganges, were closed (Garg et al. 2020). However, inputs from domestic discharge 
from households along the Ganges continued, presumably at an increased rate, during the lockdowns. The pollution sources and loading to Ganges River are region specific, for example, places such as Varanasi and Haridwar being the pilgrim hotspots, are exposed to pollutants from hotels, restaurants, and shops, etc., along with ambient baseline pollution from the rest of the urban activities (CPCB 2020). Sites near Kanpur and Bakhtiarpur (Patna) are mostly influenced by industrial inputs (CPCB 2020). In contrast, regions near Rishikesh receive the least domestic inputs due to lesser anthropogenic activity and settlement (Garg et al. 2020; CPCB 2020). In downstream regions, Garden Reach and Dimond Harbour sites receive the effluents discharged from upstream all along the Ganges stretch before draining to the Bay of Bengal.

In the recent past, India's news media has widely reported that because of the lockdown, the Ganges water has been revived up to the extent that it is now potable. For example, it was reported that the Ganges experienced a reduction in biochemical oxygen demand (BOD), chemical oxygen demand (COD) concentration, an overall improvement especially with regard to increased dissolved oxygen (DO), and reduced nitrate concentration was due to relatively less discharge of domestic wastewater (New Indian Express 2020a, b; Times of India 2020a, b). During the peak of the lockdown, it was also reported that the overall water pollution declined up to $50 \%$ as the pollution sourced from industries was stopped due to the lockdowns (Times of India 2020a, b; Hindustan Times 2020; New Indian Express 2020a, b). As per the report by DownToEarth (2020), the water quality DO, BOD, $\mathrm{pH}$, and ammonia levels became suitable for bathing and use by wildlife and fisheries during the lockdown period. Several news stories went so far as to report that the Ganges water has become fit for drinking during the peak of the lockdowns (New Indian Express 2020b; BBC News 2020; India TV News 2020). Contrasting to all this news, The Hindu (2020) reported that even though the lockdown dramatically reduced air pollution across the country, it has not significantly reduced pollution in the Ganges River as the reduction in BOD and COD was not significant enough (CPCB 2020). Despite the news reports, there has not been much scientific evidence published to date except a few studies on the upstream of Ganges at Haridwar, Kanpur, Varanasi, and Prayagraj (Garg et al. 2020) and lower stretch of the river Ganges (i.e. Bhaghirathi-Hoogly river) in West Bengal segment (Mukherjee et al. 2020; Dhar et al. 2020), which provided some evidence of improved water quality.

As reported by these studies, the improvement in water quality was in reference to parameters such as DO, BOD, COD, $\mathrm{pH}$, turbidity, and ammonia in different locations. None of the parameters can be solely used to represent the quality of the water to be fit for drinking, bathing, or used by livestock. But as a group, these parameters can designate the best use based on pre-established thresholds for each (CPCB 1986, BIS: 2296:1992). Apart from these parameters, chromophoric dissolved organic matter (CDOM), total suspended matter (TSM), and chlorophyll-a (Chl-a) also represent the quality of water and can be measured through remote sensing techniques in the case of the absence of field data for a particular period and location. Since during the lockdowns, field data collection was not feasible, remote sensing techniques were used for the assessment of environmental changes (Garg et al. 2020). Among these three parameters, CDOM serves as a good indicator of anthropogenic influences including land surface runoff and sewage water pollution, and water quality contamination for the riverine systems (Baker 2001; Zhao et al. 2017a, b). It also acts as a good proxy for the dissolved organic carbon (DOC), biochemical oxygen demand (BOD), chemical oxygen demand (COD), and heavy metals (Kowalczuk et al. 2010; Shao et al. 2016; Zhou et al. 2016; Kutser et al. 2017). TSM is a measure of suspended organic and inorganic materials in the river waters (Giardino et al. 2017). TSM and Chl-a are widely used as proxies for the riverine water quality in terms of eutrophication. Chl-a, a proxy for trophic status, is often used to assess the ecological response of a water body to excessive pollution (Mishra and Mishra 2012).

In the present study, remote sensing techniques were utilized to estimate three water quality parameters, viz., CDOM, TSM, and Chl-a, and compared their temporal dynamics at seven stations over three months (March-May, 2020) to disentangle their temporal variations and isolate the impact of the lockdown. This is the first study focused on the three parameters for a comprehensive assessment of the changes in the Ganges water quality as compared to pre-lockdown period along the entire stretch of the Ganges, i.e. from upstream (Rishikesh in the north) to downstream (Diamond Harbour in the east) through remote sensing approach.

\section{Materials and methods}

TSM, Chl-a, and CDOM (absorption of CDOM or aCDOM) of seven selected locations were derived from satellite data and mapped for periods before and during the lockdown. The selected locations were Rishikesh and Haridwar from the upper stream (Uttarakhand), Kanpur, Varanasi, and Bakhtiarpur from the middle stream (Uttar Pradesh and Bihar) and Garden Reach and Diamond Harbour (West Bengal) as downstream stations closer to the Bay of Bengal (Fig. 1). These study sites were selected (the rectangular regions in Fig. 1) based on various criteria including the depth, proximity to the city, and swatch covered by induvial Sentinel 2 scenes.

Sentinel 2-multi-spectral instrument (MSI) Level-2A surface reflectance (SR) data was used which is an atmospherically corrected product available in Google Earth Engine (GEE). The original source of these GEE products is the European Space Agency's (ESA) scientific data hub website (https://scihub.coper nicus.eu/dhus/\#/home). First, cloud-free (less than 20\% cloudcover) satellite images were checked for each site for each month 


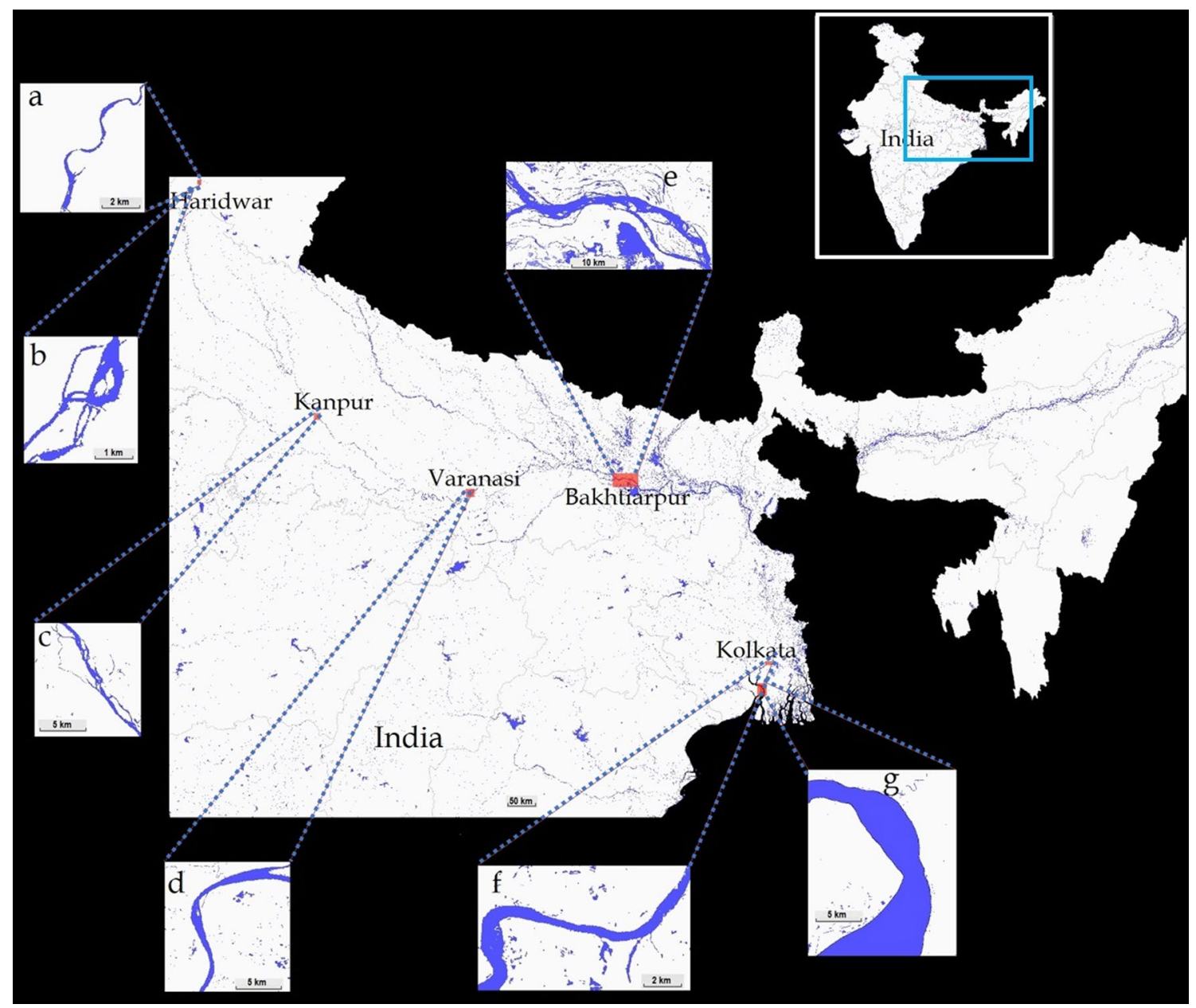

Fig. 1 Seven selected locations along the Ganges stretch a Rishikesh, b Haridwar, c Kanpur, d Varanasi, e Bakhtiarpur, f Garden Reach, and $\mathbf{g}$ Diamond Harbour

(March-May) of 2020. These cloud-free SR products were imported into Google Earth Engine (GEE) platform for further processing, visualization, and data extraction. For each month, a mean composite SR image was created by spatially averaging pixel values of all available cloud-free pixels for that particular month (Table 1). Next, sun glint and non-water pixels were masked using short-wave infrared (SWIR) band SR threshold before implementing the bio-optical remote sensing algorithms. Three separate remote sensing models were used to derive Chla, aCDOM, and TSM using Sentinel 2-MSI bands (Eqs. 1-4):

Table 1 Sentinel 2-MSI images used in creating monthly composite products (pre-lockdown and post-lockdown) for each study site

\begin{tabular}{llll}
\hline S. No. & Study site & Satellite image dates & \\
\cline { 3 - 4 } & & Pre-lockdown (Mar. of 2020) & During lockdown (Apr-May of 2020) \\
\hline 1 & Rishikesh & 10th, 20th and 25th of March 2020 & 4th, 19th and 24th of April 2020 \\
2 & Haridwar & 10th, 15th, 20th and 30th of March 2020 & 4th, 19th and 24th of April 2020 \\
3 & Kanpur & 2nd, 9th,19th and 29th of March 2020 & 3rd and 8th of April and 8th of May 2020 \\
4 & Varanasi & 6th and 31st of March 2020 & 5th and 10th of April and 5th of May 2020 \\
5 & Bakhtiarpur & 18th and 23rd March 2020 & 2nd, 12th and 17th of April and 17th of May \\
6 & Garden reach & 5th, 10th, 15th, 20th and 30th of March 2020 & 2020 14th of April 2020 \\
7 & Diamond Harbour & 15th and 30th of March 2020 & 19th, 29th of April and 9th of May 2020 \\
\hline
\end{tabular}


Chl-a $=14.039+86.115 \times \mathrm{NDCI}+194.325 \times \mathrm{NDCI}^{2},(1)$

$\mathrm{NDCI}=\frac{\rho(705)-\rho(665)}{\rho(705)+\rho(665)}$

where $\rho$ is surface reflectance at $705 \mathrm{~nm}$ and $665 \mathrm{~nm}$ of Sentinel 2-MSI bands.

$a_{\mathrm{CDOM}}(355)=6.68 \times\left(\frac{\rho(560)}{\rho(665)}\right)^{-3.12}$,

where, ${ }^{a}$ CDOM (355) is the absorption coefficient of CDOM at $355 \mathrm{~nm}$.

$\mathrm{TSM}=\frac{355.85 \times \rho(665)}{1-\frac{\rho(665)}{0.1728}}+1.74$

Though these three models were calibrated and validated at other study sites, they have been used widely by numerous remote sensing studies. Chl-a model (Eqs. 1,2$)\left(R^{2}=0.95\right.$; $p<0.0001$; range $=1-60 \mu \mathrm{g} / \mathrm{L} ; \mathrm{RMSE}=2 \mu \mathrm{g} / \mathrm{L})$ was developed by Mishra and Mishra (2012), aCDOM model (Eq. 3) $\left(R^{2}=0.74 ; p<0.0001 ;\right.$ range $\left.=1.25-8.54 / \mathrm{m} ; \mathrm{RMSE}=1.16 / \mathrm{m}\right)$ by Joshi and D'Sa (2015), and TSM model (Eq. 4) $\left(R^{2}=0.89\right.$; $\mathrm{RMSE}=12.79 \mathrm{mg} / \mathrm{L}$; range $=1.24-110.27 \mathrm{mg} / \mathrm{L}$ ) was developed by Nechad et al. (2010). After implementing these models, the mean and standard deviation (using all the valid water pixels within the rectangular area of each site in Fig. 1) were extracted for each parameter for each month for all seven sites. Analysis of variance (ANOVA) was performed on the data to see the spatio-temporal variation. The area used to compute the mean and standard deviation of each parameter for each site is shown in Fig. 2a-c. TSM (mg/L) values converted to turbidity (NTU) for comparison with thresholds, prescribed for drinking water quality, using the liner conversion equation, turbidity $=\mathrm{TSS} / 3.4216$ (https://www.alberta.ca/assets/documents/ tr-conversion-of-nephelometric-turbidity-units.pdf).

\section{Results and discussion}

The Sentinel-2 derived maps of Chl-a, aCDOM, and TSM concentration and spatial distribution at the seven locations are depicted in Fig. 2. The spatial gradient pattern of all three water quality parameters showed significant variations across sites (ANOVA $P<0.05 ; n=13$ ). Irrespective of the month, the TSM and aCDOM showed an increasing pattern from upstream to downstream, whereas Chl-a did not show any specific trend. The increasing pattern might be due to runoff from the catchmentassociated sediment transport, increase in the urban development, population settlement, and their associated domestic activities along the river Ganges (GRBEMP-Interim Report 2013; NMCG-NEERI Ganga Report 2017). At Rishikesh, TSM was found to be the lowest which could be due to the drastic reduction in tourist activities (Bajpai et al. 2015). A significant decline in TSM was also recorded at Haridwar and Varanasi up to 55\% and $40 \%$ (Fig. 3a), respectively, due to the halt in pilgrimage, tourism, and associated sewage from hotels, lodges, restaurants, shops. Accordingly, the TSM concentration was expected to be lowest in the downstream locations as TSM load declined as a result of lockdown in the upper streams. However, the highest TSM was observed at Diamond Harbour followed by Garden Reach (Fig. 2a). This could be due to the fact that the lower reaches of the river are strongly influenced by the tide, the tidal fluctuation with the intrusion of saline waters which disturbs the bottom sediments and allows to suspend the sediments in the entire water column (Sinha et al. 1997; Rose et al. 2015). Hence, the impact of lockdown at these locations is shown to be dominated by the tidal impact and bottom sediment mixing. At Haridwar, the estimated turbidity value before the lockdown was 14 NTU, whereas it was declined to 6 NTU during the lockdown, indicating that the waters became potable at Haridwar as per the threshold ( $<10 \mathrm{NTU})$ prescribed in Indian standards for drinking water (BIS 10500:1991) by Indian Standard Institution (ISI) and Central Pollution Control Board (CPCB) (Kumar and Puri 2012). These results validate a few published reports (e.g. New Indian Express 2020a; b; BBC News 2020) which reported the portability of water at Haridwar.

Chl-a has been used as a common parameter for water quality index along with transparency and nutrients (Smith et al. 1999; Carlson 1977; Kratzer and Brezonik 1981). The mean Chl-a concentrations increased in the middle stretches of the river and decreased towards the down stretch (Fig. 3b). This might be due to the persistence of stable environmental conditions, viz. availability of micronutrients, at the middle stretch as compared to lower stretch which represents estuarine environmental characteristics (Sarma et al. 2010). Even though the lower reaches possess adequate nutrient levels, unfavourable environmental conditions such as high turbidity limit the photic depth and reduce the Chl-a level. Sarma et al. (2010) also observed a similar trend in the Godavari estuarine system. Chl-a was expected to increase in the regions where TSM declined as a result of the lockdown (Muduli and Pattnaik 2020; Ganguly et al. 2013). Chl-a was also expected to decrease in the entire stretch of the Ganges due to an anticipated decline in nutrient load from agricultural activities, domestic settlements, sewage, industrial effluents because of lockdown. However, such trends were not found which could be due to the fact that the changes were typically controlled by in situ biological and physical processes, viz. availability of sunlight, water temperature, phytoplankton abundance, and growth rate (Kanuri et al. 2013; Ganguly et al. 2013). Also, the Chl-a concentration is mostly dependent on the micronutrients such as dissolved inorganic nitrogen and phosphate which are not the limiting nutrients in Ganges waters (Kanuri et al. 2020; Mitra et al. 2018; Dwivedi et al. 2018). 


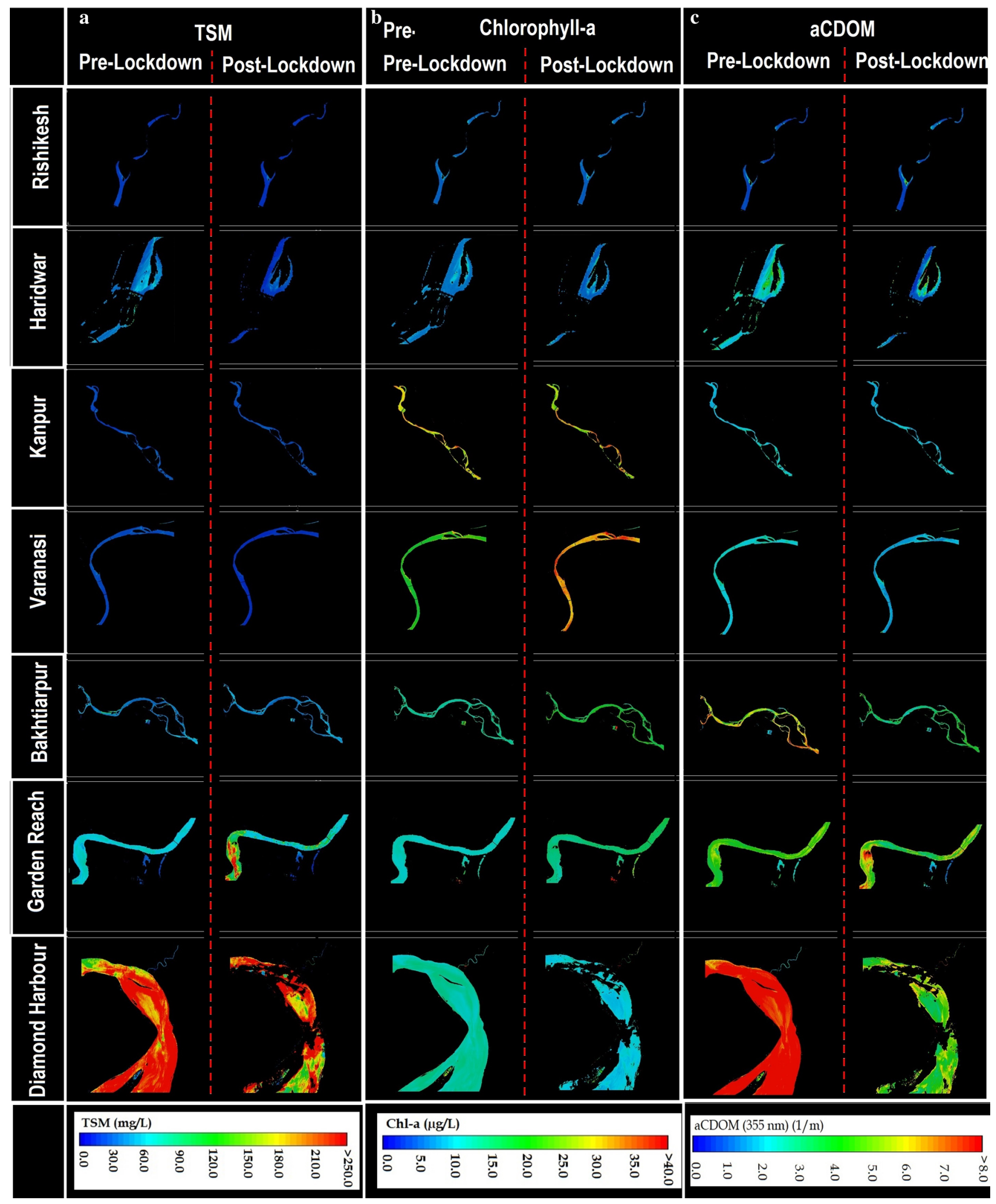

Fig. 2 Sentinel 2-MSI spatial distribution maps of a TSM, b Chl-a, and $\mathbf{c}$ aCDOM at seven locations along the Ganges stretches 


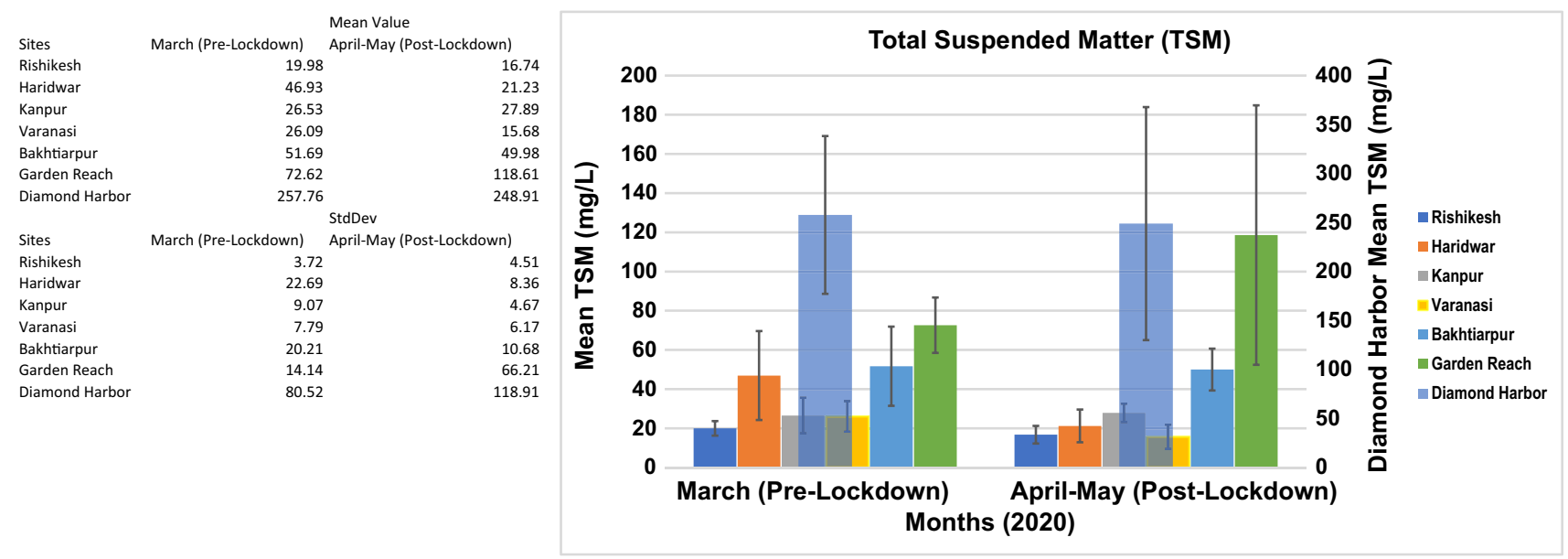

(a)
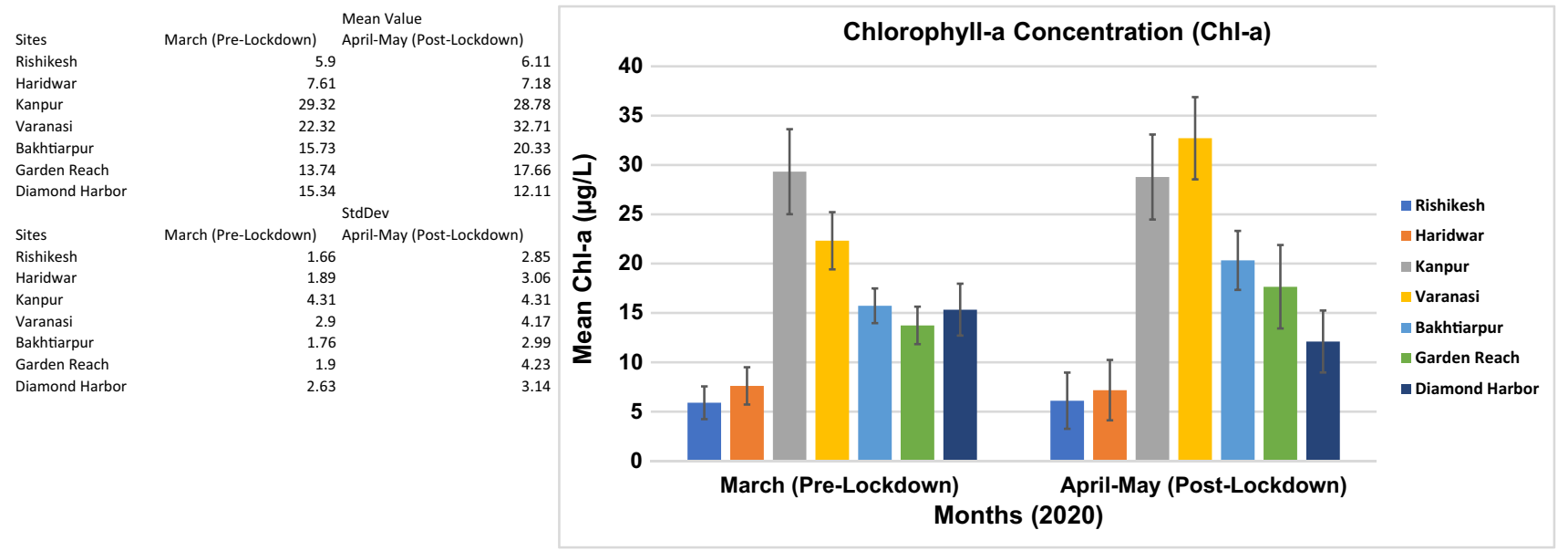

(b)

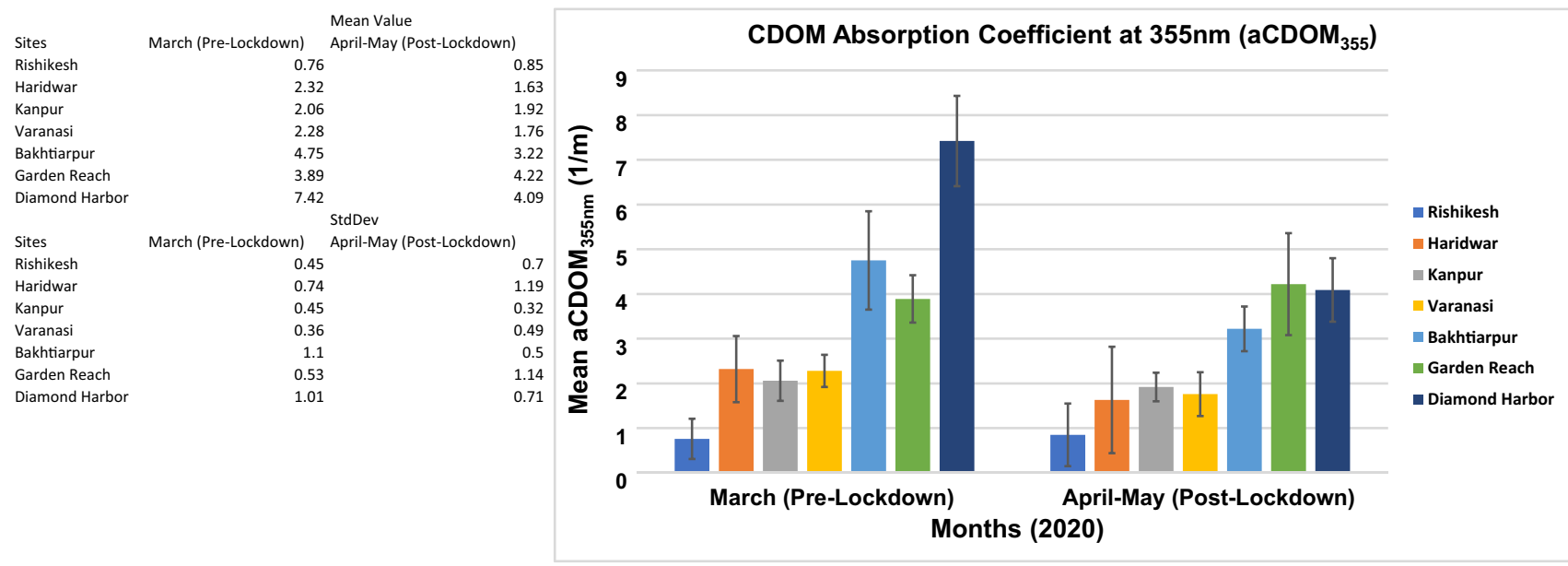

(c)

Fig. 3 Variations in water quality parameters a TSM, b Chl-a, c aCDOM along the Ganges stretches. A secondary axis was used to show TSM of Diamond Harbour. The error bars represent standard deviation $( \pm 1 \sigma)$ from mean) 
CDOM is a proxy for organic pollution in the inland and coastal waters. The CDOM absorption coefficient (aCDOM) maps showed a significant spatial gradient (Fig. 3). aCDOM increased from extreme upstream to downstream irrespective of the study period (Fig. 3c). A decline in aCDOM was observed due to the lockdowns, but the magnitude of decline was the sharpest at the most downstream location. The aCDOM (at $355 \mathrm{~nm}$ ) was found to be high during the pre-lockdown period as compared to the lockdown period at all the locations except Rishikesh and Garden Reach. The percentage decrease in the aCDOM was found to be $>25 \%$. The distribution of aCDOM varied differently from the distribution of Chl-a and did not show any significant spatial relationship between each other. Several researchers have shown that the extracellular metabolites produced during phytoplankton production, and microbial processing of phytoplankton-derived aggregates are the major sources of CDOM in inland and coastal marine environments (Zhang et al. 2009; Chari et al. 2013; Kinsey et al. 2018). Hence, one can expect a significant positive correlation between Chl-a and aCDOM. However, in the present study, the satellite estimates did not show such a relationship which indicated that the source of CDOM was mostly linked to anthropogenic activities. Also, as per the report on the impact of lockdown on water quality of Ganges River published by CPCB (2020), the BOD and COD concentration, which also represent organic matter pollution like CDOM, along the river (i.e. upstream to downstream) were significantly declined. However, the improvement in water quality was only suitable for bathing and not enough to meet the drinking water quality standards.

\section{Conclusion}

From the results of the present study, it is concluded that due to COVID-19 lockdown, the minimal (or no) discharge of industrial effluent, urban runoff, pilgrimage, and tourism-related wastewater helped improve the water quality of the Ganges up to some extent at specific locations. Waters at Haridwar found to become potable because of the lockdown but with respect to turbidity only. However, other parameters such as toxic trace metals, organic pollutants such as pesticides, PAH (polycyclic aromatic hydrocarbon), TPHC (total petroleum hydrocarbon), and FC (fecal coliform), which need to be studied and compared against the approved threshold values to confirm its actual potability. aCDOM showed a prominent change with reference to the lockdown impact as compared to TSM and Chl-a, and hence it can be considered as a proxy for industrial and anthropogenic impacts on river water quality. These results can be used as the baseline data for monitoring future changes of water quality in the Ganges as the anthropogenic activities resume with time. The results can be helpful for several ongoing modelling studies on the Ganges aimed at predicting hydrological parameters as well as pollution in relation to changing environmental conditions due to anthropogenic activities. The limitation of the present study is the absence of field data which could not be acquired due to lockdown; therefore, future study must include the ground truth data for model validation and tuning.

Since the study demonstrated successful implementation of satellite data for monitoring Ganges water quality, it is recommended that future studies use satellite-based analysis to map parameters such as dissolved organic matter, nutrients, conductivity, TSM, and water temperature either through direct satellite-derived values or through indirect models and algorithms. It would be helpful for the policymakers to develop and establish short-term or long-term based management and mitigation plans. Continuous monitoring of the entire stretches of the Ganges River should be carried out to observe the changes after the lifting of the lockdown restrictions and all anthropogenic input return to pre-pandemic levels.

Acknowledgements The authors are thankful to the Department of Geography at the University of Georgia for providing financial support and facilities for satellite data processing and modelling.

\section{Declarations}

Conflict of interest The authors declares that there is no conflict of interest.

Ethical approval This article does not contain any studies with human participants or animals performed by any of the authors.

\section{References}

Bajpai AK, Yadav AS, Pandey DC (2015) Tourism and tourist influx evaluation and analysis in Haridwar and Rishikesh townships of Uttarakhand. Glob J Multidiscip Stud 4(12):225-231

Baker A (2001) Fluorescence excitation - emission matrix characterization of some sewage-impacted rivers. Environ Sci Technol. https://doi. org/10.1021/es000177t

BBC News 2020 (https://www.bbc.com/news/av/world-asia-india-52290 522)

Carlson RE (1977) A trophic state index for lakes. Oceanogr Limnol. https ://doi.org/10.4319/lo.1977.22.2.0361

Chari NVHK, Sudarsana Rao P, Sarma NS (2013) Fluorescent dissolved organic matter in the continental shelf waters of western Bay of Bengal. J Earth Syst Sci 122:1325-1334. https://doi. org/10.1007/s12040-013-0349-0

CPCB 1986 https://parivesh.nic.in/writereaddata/ENV/eprotect_act_1986. pdf

CPCB (2020) A report on impact of lockdown on water quality of river ganga. Central pollution control board, Delhi. Ministry of Environment, Forest and Climate Change, Govt. of India

Dhar I et al (2020) COVID-19 Lockdown phase: a boon for the River Ganga water quality along the city of Kolkata. Journal of the Centre for Regulatory Studies, Governance and Public Policy. NUJS J Regul Stud. https://nujs.edu/crsgpp/crsgpp-journal-april 2020.pdf

DownToEarth (2020) (https://www.downtoearth.org.in/blog/covid -19-lockdown-a-ventilator-for-rivers-70771)

Dwivedi S, Mishra S, Tripathi RD (2018) Ganga water pollution: a potential health threat to inhabitants of Ganga basin. Environ Int. https://doi.org/10.1016/j.envint.2018.05.015 
Ganguly D et al (2013) Variable response of two tropical phytoplankton species at different salinity and nutrient condition. J Exp Mar Biol Ecol. https://doi.org/10.1016/j.jembe.2013.01.008

Garg V, Aggarwal SP, Chauhan P (2020) Changes in turbidity along Ganga River using Sentinel-2 satellite data during lockdown associated with COVID-19. Geomat Nat Hazards Risk 11:11751195. https://doi.org/10.1080/19475705.2020.1782482

Giardino C et al (2017) Bio-optical modeling of total suspended solids. In: Mishra DR, Ogashawara I, Gitelson A (eds) Bio-optical modeling and remote sensing of inland waters. Elsevier, pp 101-128. https://doi.org/10.1016/B978-0-12-804644-9.00005-7

GRBEMP-Interim Report (2013) Ganga River basin environment management plan: interim report: IIT consortium: August 2013. http://mowr.gov.in/sites/default/files/GRBEMPInterimRe port_2.pdf

Hindustan Times (2020) https://www.hindustantimes.com/india -news/covid-19-lockdown-pollution-in-ganga-declines-as-facto ries-in-up-uttarakhand-remain-shut/story-ZKGahS4TVfIQqLA OQyHSxM.html

India TV News (2020) https://www.indiatvnews.com/news/india/ coronavirus-covid-19-ganga-water-quality-improves-safe-todrink-607627

Joshi I, D'Sa EJ (2015) Seasonal variation of colored dissolved organic matter in barataria bay, Louisiana, using combined landsat and field data. Remote Sens. https://doi.org/10.3390/ rs70912478

Kanuri V et al (2013) Plankton metabolic processes and its significance on dissolved organic carbon pool in a tropical brackish water lagoon. Cont Shelf Res. https://doi.org/10.1016/j.csr.2013.04.006

Kanuri VV et al (2020) Sewage fluxes and seasonal dynamics of physicochemical characteristics of the Bhagirathi-Hooghly River from the lower stretch of River Ganges, India. Chem Ecol. https://doi. org/10.1080/02757540.2019.1692826

Kinsey JD et al (2018) Formation of chromophoric dissolved organic matter by bacterial degradation of phytoplankton-derived aggregates. Front Mar Sci 4:1-16. https://doi.org/10.3389/fmars.2017.00430

Kowalczuk P et al (2010) Characterization of dissolved organic matter fluorescence in the South Atlantic Bight with use of PARAFAC model: relationships between fluorescence and its components, absorption coefficients and organic carbon concentrations. Mar Chem. https:// doi.org/10.1016/j.marchem.2009.10.002

Kratzer CR, Brezonik PL (1981) A carlson-type trophic state index for nitrogen in Florida lakes. JAWRA J Am Water Resour Assoc. https ://doi.org/10.1111/j.1752-1688.1981.tb01282.x

Kumar M, Puri A (2012) A review of permissible limits of drinking water. Indian J Occup Environ Med 16:40-44. https://doi. org/10.4103/0019-5278.99696

Kutser T et al (2017) Bio-optical modeling of colored dissolved organic matter. In: Mishra DR, Ogashawara I, Gitelson A (eds) Bio-optical modeling and remote sensing of inland waters. Elsevier, pp 101-128. https://doi.org/10.1016/B978-0-12-804644-9.00004-5

Mishra S, Mishra DR (2012) Normalized difference chlorophyll index: a novel model for remote estimation of chlorophyll-a concentration in turbid productive waters. Remote Sens Environ. https://doi. org/10.1016/j.rse.2011.10.016

Mishra DR et al (2020) Decline in phytoplankton biomass along Indian Coastal waters due to COVID-19 lockdown. Remote Sens 12:2584. https://doi.org/10.3390/rs12162584

Mitra S et al (2018) Water quality assessment of the ecologically stressed Hooghly River Estuary, India: a multivariate approach. Mar Pollut Bull. https://doi.org/10.1016/j.marpolbul.2017.09.053

Muduli PR, Pattnaik AK (2020) Spatio-temporal variation in physicochemical parameters of water in the Chilika Lagoon. In: Finlayson C, Rastogi G, Mishra D, Pattnaik A (eds) Ecology, conservation, and restoration of Chilika Lagoon, India. Wetlands: ecology, conservation and management, vol 6. Springer, Cham
Mukherjee P et al (2020) Eco-restoration of River Ganga water quality during COVID-19 lockdown period using Total Coliform (TC) as proxy. Journal of the Centre for Regulatory Studies, Governance and Public Policy. NUJS J Regul Stud. https://nujs.edu/crsgpp/crsgp p-journal-april2020.pdf

Nechad B, Ruddick KG, Park Y (2010) Calibration and validation of a generic multisensor algorithm for mapping of total suspended matter in turbid waters. Remote Sens Environ. https://doi.org/10.1016/j. rse.2009.11.022

New Indian Express (2020a) https://www.newindianexpress.com/natio n/2020/apr/28/ganga-water-quality-improves-thanks-to-covid-19lockdown-across-india-2136265.html

New Indian Express (2020b) https://www.newindianexpress.com/natio n/2020/may/08/lockdown-effect-ganga-water-fit-for-drinking-after -decades-say-experts-2140622.html

NMCG-NEERI Ganga Report (2017) Assessment of water quality and sediment to understand the special properties of River Ganga. https:// nmcg.nic.in/writereaddata/fileupload/NMCGNEERI\%20Ganga\%20 Report.pdf

Rose L, Bhaskaran PK, Kani SP (2015) Tidal analysis and prediction for the Gangra location, Hooghly estuary in the Bay of Bengal. Curr Sci. https://doi.org/10.18520/cs/v109/i4/745-758

Sarma VVSS et al (2010) Intra-annual variability in nutrients in the Godavari estuary, India. Cont Shelf Res. https://doi.org/10.1016/j. csr.2010.10.001

Shao $\mathrm{T}$ et al (2016) Characteristics and sources analysis of riverine chromophoric dissolved organic matter in Liaohe River, China. Water Sci Technol. https://doi.org/10.2166/wst.2016.457

Sinha PC et al (1997) Effect of sea level rise on tidal circulation in the hooghly estuary, Bay of Bengal. Mar Geod. https://doi. org/10.1080/01490419709388114

Smith VH, Tilman GD, Nekola JC (1999) Eutrophication: impacts of excess nutrient inputs on freshwater, marine, and terrestrial ecosystems. Environ Pollut. https://doi.org/10.1016/S0269-7491(99)00091 $-3$

The Hindu (2020) https://www.thehindu.com/sci-tech/energy-and-envir onment/coronavirus-lockdown-no-improvement-in-ganga-water -quality/article31457326.ece

Times of India (2020a) https://timesofindia.indiatimes.com/india/howlockdown-has-been-a-gift-for-river-ganga/articleshow/75569852.cms

Times of India (2020b) https://timesofindia.indiatimes.com/india/lockd own-improves-water-quality-of-ganga-yamuna/articleshow/75456 921.cms

Yunus AP, Masago Y, Hijioka Y (2020) COVID-19 and surface water quality: improved lake water quality during the lockdown. Sci Total Environ 731:139012. https://doi.org/10.1016/j.scitotenv.2020.139012

Zhang Y, van Dijk MA, Liu M, Zhu G, Qin B (2009) The contribution of phytoplankton degradation to chromophoric dissolved organic matter (CDOM) in eutrophic shallow lakes: field and experimental evidence. Water Res 43(18):4685-4697. https://doi.org/10.1016/j. watres.2009.07.024

Zhao Y et al (2016) Characterization of CDOM from urban waters in Northern-Northeastern China using excitation-emission matrix fluorescence and parallel factor analysis. Environ Sci Pollut Res. https:// doi.org/10.1007/s11356-016-6703-4

Zhao Y et al (2017a) Characterization of CDOM of river waters in China using fluorescence excitation-emission matrix and regional integration techniques. J Geophys Res Biogeosciences 122:1940-1953. https ://doi.org/10.1002/2017JG003820

Zhao Z et al (2017b) Picocyanobacteria and deep-ocean fluorescent dissolved organic matter share similar optical properties. Nat Commun. https://doi.org/10.1038/ncomms15284

Zhou Z et al (2016) Colloidal size spectra, composition and estuarine mixing behavior of DOM in river and estuarine waters of the northern Gulf of Mexico. Geochim Cosmochim Acta. https://doi. org/10.1016/j.gca.2016.02.032 